\title{
POLITICAL AND NATIONALISM OF GP ANSOR IN FACING THE PERSSECUTION OF KIRAB SATU NEGERI IN THE MERANTI ISLANDS
}

\section{Imam Ghozali and Junaidi}

Sekolah Tinggi Agama Islam Negeri Bengkalis, Indonesia email: imamghozalikampusmelayu@gmail.com,

filsafat21@gmail.com

Abstract: This study is to determine the implementation, implication, and process of resolving the politics of nationalism in the Kirab Satu Negeri GP Ansor activities in the Meranti Islands. This activity experienced persecution from HTI, FPI, youth organizations, and the Malay Customary Institution (LAM) of the Meranti Islands Regency. The movement of negative opinions by these mass organizations has worsened the image of GP Ansor in the Meranti community. This research uses a qualitative descriptive-analytic approach. The data collection method in this study combines the Library Method and Field Research. As a result of the research, GP Ansor applies the politics of religious nationalism in carrying out the Kirab Satu Negeri. Indeed, radicalism groups and youth organizations build negative opinions of political and religious issues the affect the solidity of members of the GP Ansor, divided into two, namely following the line of command of the GP Ansor board and some rejecting it firmly. The GP Ansor militant committee consistently moves to resolve the persecution with religious nationalism politics, namely: first to open a dialogue with mass organizations that reject the KSN program; second, to conduct friendship wit LAM elders with the connectivity approach of the similarity between the NU tradition and the rituals of the Malay community; the third structural approach to the local Government, DPRD and Kapolres regarding the KSN mission to arouse the spirit of nationality; fourth, inviting all members of the GP Ansor, officials 
to do istighosah so that Indonesia will not be able to be divided by radical groups.

الملخص: تهدف هذه الدراسة إلى تحديد التنفيذ والتضمين وعملية حل المشكلة حول

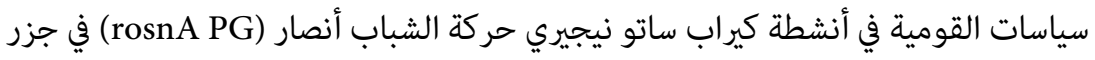

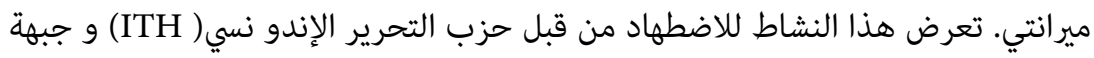

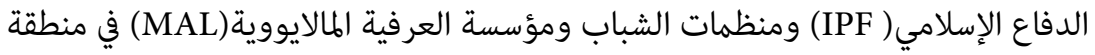

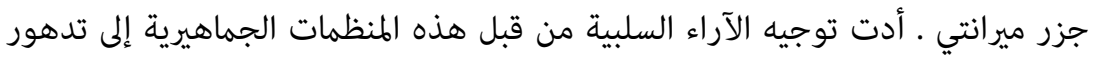

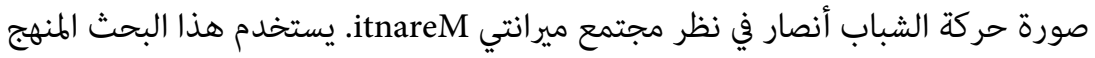

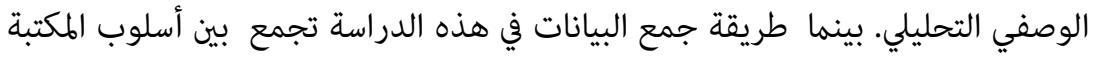

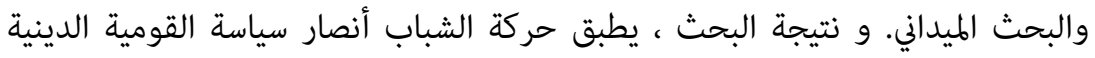

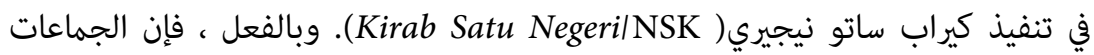

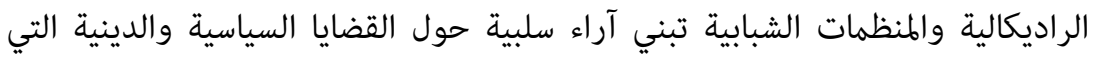

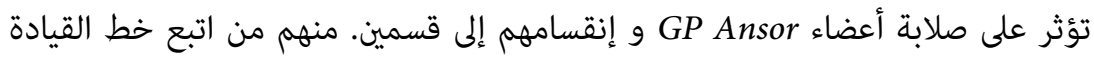

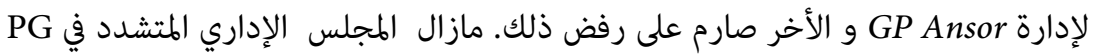

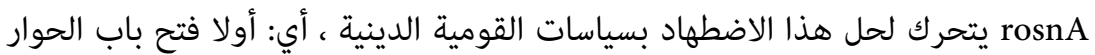

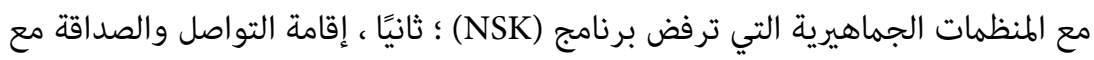

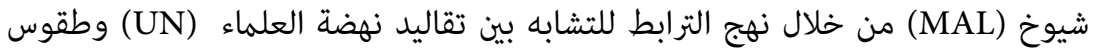

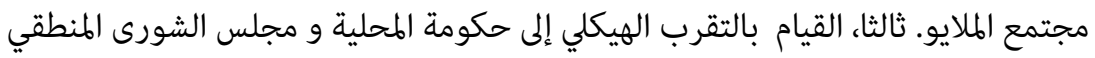

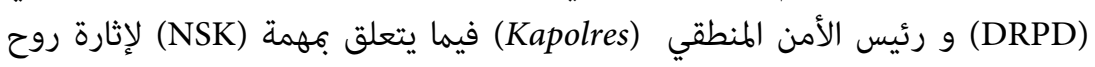

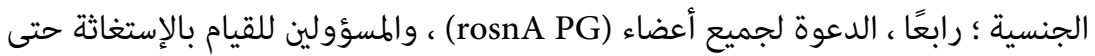
تتجنب الدولة الإندونيسية من الانقسام بسبب عمل الجماعات المتطرفة.

Abstrak: Penelitian ini untuk mengetahui implementasi, implikasi dan proses penyelesaian politik nasionalisme pada kegiatan Kirab Satu Negeri (KSN) GP Ansor Kepulauan Meranti. Kegiatan ini mengalami persekusi dari HTI, FPI, Ormas Kepemudaan dan Lembaga Adat Melayu (LAM) Kabupaten Kepulauan Meranti. Penggiringan opini negatif oleh kelompok Ormas-ormas tersebut telah memperburuk citra GP Ansor di masyarakat Meranti. Penelitian ini menggunakan pendekatan kualitataif deskriptif analistis. Sedangkan metode pengumpulan data dalam penelitian ini menggabungkan antara metode kepustakaan dan 
penelitian lapangan. Hasil penelitian menyimpulkan bahwa GP Ansor menerapkan politik nasionalisme religius dalam menjalankan Kirab Satu Negeri. Kelompok radikalisme dan Ormas kepemudaan membangun opini negatif tentang isu-isu politik dan agama yang mempengaruhi solidaritas anggota $G P$ Ansor sehingga terpecah menjadi dua, yaitu sebagian mengikuti garis komando pengurus GP Ansor dan sebagain menolak secara tegas. Pengurus militan GP Ansor konsisten terus bergerak menyelesaikan persekusi dengan politik nasionalisme religius, yaitu pertama membuka dialog dengan Ormas-ormas yang menolak acara KSN; kedua melakukan silaturahi dengan sesepuh LAM dengan pendekatan konektivitas kesamaan antara tradisi NU melalui ritual masyarakat Melayu; ketiga melakukan pendekatan struktural kepada Pemuda, DPRD dan Kapolres tentang misi KSN untuk membangkitkan semangat kebangsaan; keempat mengajakseluruh anggota GP Ansor, para pejabat untuk istighasah agar negara Indonesia terhindar dari perpecahan akibat dari kelompok-kelompok radikalisme.

Keywords: nationalism politics, GP Ansor, Kirab Satu Negeri, persecution.

\section{INTRODUCTION}

Kirab Satu Negeri (KSN) is the embodiment of the Nationalism Politics of the Ansor Youth Movement (GP Ansor) throughout the archipelago. The Jihad Hasyim Asy'arire solution stipulating the mandatory law to maintain independence in the life of the nation and state has become the foundation of GP Ansor againsts radicalism groups that continue to develop in line with dynamics at home and abroad. ${ }^{1}$ In 2019, radical groups have a place to convey their political aspirations by supporting the pairs of Prabowo Subianto and Sandiaga Uno. They take refuge in the constitution following the KhawarijStyle democratic process, namely conducting the electoral process

1 A. Jauhar Fuad, "Gerakan Kultural Dan Pemberdayaan: Sebuah Imun Terhadap Radikalisasi Di Sanggar Sekar Jagad Sukoharjo," Al-Tahrir: Jurnal Pemikiran Islam 18, No.1 (Mei 2018): 3. 
and often holding demonstrations that are forbidden by themselves. ${ }^{2}$ Armed with the constitution, they are free to criticize GP Ansor for carrying out a ruler who according to him has closed democratic freedom, criminalized Ulama, and discriminated against Muslims. Even on various campaigns and preaching activities, they often fly the HTI Flag by taking cover in the name of the «Tauhid Flag". They also accused GP Ansor of being an organization that insulted Islam by burning the Tauhid flag and carrying out the persecution of their Islamic scholars (Ulama).

The hatred towards GP Ansor was vented at the implementation of KSN in the Meranti Islands regency. Religious and youth organizations such as HTI, FPI, Pemuda Pancasila, Pemuda Panca Marga, and various other youth organizations together with the Malay Customary Institution (LAM) carry out the persecution of KSN activities. Religion-based intolerance is caused by widespread practices of spreading hatred in certain communities, besides that there is not much room for dialogue between different communities. ${ }^{3}$ Religion should be a savior for humans, but when the power of radicalism strengthens, it will become a threat to anyone. ${ }^{4}$ As a result, they committed acts of intolerance towards GP Ansor, who had been in Meranti Island Regency since 1965 and had contributed greatly to the Meranti community in the religious and social fields. ${ }^{5}$

The existence of GP Ansor which has long been a part of the community, suddenly received a rejection in the KSN activities. It is certainly interesting to investigate their attitude in solving the persecution problem that befell it. Several researchers have previously discussed the GP Ansor in various aspects of the study. First, the results of research by Ahmad Subakir and Ahmad Khoirul Mustawir,

2 Imam Ghozali, "Memahami Format Demokrasi Model Khawarij Di Indonesia (Studi Kasus Pemilihan Presiden Tahun 2019)," Islamadina Jurnal Pemikiran Islam 21 (March 1, 2020): 20.

3 Septi Gumiandari and Nafi'a Ilman, "The Role of Cirebon Women Ulama in Countering Religious Radicalism," QIJIS (Qudus International Journal of Islamic Studies) 8, No. 1 (2020): 1.

4 Abdul Adzim, "Religious Harmonization as Deradicalisation Efforts Through Interfaith Communities - A Case Study of the Religious Communication Forum (FKUB) in Pekalongan City," Islamic Studies Journal for Social Transformation 3, No. 1 (2019): 21.

5 Kyai Kholik, "interview on Kirab Satu Negeri in Kabupaten Kepulauan Meranti," 2020. 
regarding the strategy of GP Ansor in overcoming radicalism in the Wonoayu region of Sidoarjo by holding activities to strengthen the national ideology such as "National Recognition" by reviving local such tahlilan routine, reading shalawat al-barjanji, and istighatsah. This method is an educational step both orally and in writing about strengthening the ideology of nationality and the dangers of radicalism. In addition to strengthening Aswaja's teachings, GP Ansor also took precautions by prohibiting radicalism activities such as the Brothers Fest event which was held on July 13-14, 2020 at Gor Joyoboyo by HTI activists who had been dissolved by the Government. ${ }^{6}$

Second, the results of Imam Solichun's research explain that radicalism in the city of Surabaya is quite developing. This development is seen from the significant spread of radicalism through the process of cadre or member regeneration. GP Ansor Surabaya city is committed to rejecting and counteracting the flow of radicalism with various programs, including optimizing cadre training for skills, optimizing the zikr, and shalawat council, Cyber Army, and collaboration with various parties and scientific seminars. The role of this mass organization in counteracting radicalism is through the revitalization of the Islamic values of Ahl sunnah wa al-jama'ah in everyday life. ${ }^{7}$

Third, the research findings of Husnul Habib Sihombing and Erianjoni showed that there are four Aswaja values that are owned by GP Ansor, namely: (1) tawasuth value, (2) tawazun value, (3) tasammuh value, (4) i'tidal values. The implementation of Aswaja values in the GP Ansor in the city of Padang by conducting: basic leadership training, conducting zikr and shalawatan assemblies, caring for the people, and discussing community harmony. ${ }^{8}$

6 Ahmad Subakir and Ahmad Khoirul Mustamir, "Gerakan Moderasi Islam Dalam Perspektif Deteksi Dini; Studi Gerakan Pemuda Ansor Kota Kediri," Tribakti: Jurnal Pemikiran Keislaman 31, No. 2 (July 2020).

7 Imam Solichun, "Peran Organisasi Pemuda Dalam Menangkal Radikalisme (Studi Pada GP Ansor Kota Surabaya Periode 2017-2021),” PascaSarjana Universitas Islam Negeri Sunan Ampel Surabaya Tesis (2018).

8 Husnul Habib Sihombing and Erianjoni Erianjoni, "Internalisasi Nilai-Nilai Aswaja Pada Organisasi Gerakan Pemuda Ansor Di Kota Padang," Jurnal Perspektif 1, No. 4 (2018). 
This study is different from previous studies. First, from the subject matter, namely: the Malay Customary Institution (LAM) and youth organizations such as the KNPI, Pemuda Pancasila, Pemuda Panca Marga, HTI, and FPI in Meranti Islands Regency. Second, the object of the problem is their persecution of the KSN GP Ansor activities in the Meranti Islands. Third, the split attitudes of some members and former administrators of the GP Ansor, who were carried away and followed their thoughts.

So, one side of the GP Ansor is experiencing internal pressure related to loyalty to the oath of allegiance as a member, external pressure in the form of physical threats and verbal abuse both in the community, places of worship and places of worship and Social Media as a dislike towards Scholars, Pancasila, and NKRI mass organization. The object of this research focuses on: first, the implementation of the nationalism politics of GP Ansor in everyday life and when facing persecution at the $2018 \mathrm{KSN}$ event; second, the implications of the political attitude of GP Ansor's nationalism in the perceptions of LAM and youth organizations; third, the strategy of completing the persecution of the meranti archipelago GP Ansor at the $2018 \mathrm{KSN}$ event.

The research results of the above researchers have the same estuary, namely maintaining the political nationalism that has been mandated by K.H. Hasyim Asy'ari, which is the best choice for the diverse Indonesian nation. So, the activities of KSN as a form of nationalism fight the political provocations of the HTI and FPI models, which are a form of fundamentalism in which according to them there are only two types of society in the world, namely alnidam al-Islam (Islamic society) and al-nidam al-Jahli (jahiliyyah society). These two things cannot possibly have a meeting point, because one is right and is divine (deity), while the other is falsehood (deviant) and is Taghut. ${ }^{9}$

This thought shows that the two mass organizations have different ideological bases, thoughts, and movement strategies from previous Islamic mass organizations. They are suspected of having a more militant, scripturalist, conservative, and exclusive character. HTI is also known to be the most radical in the sense that it is not

9 Muhamad Tisna Nugraha, "Fundametalisme Pendidikan Agama Di Jejaring Sosial," Al-Tahrir: Jurnal Pemikiran Islam 18, No.1 (Mei 2018): 51. 
onlya struggling to uphold Islamic Law but more than that it also establishes an Islamic caliphate. ${ }^{10}$

\section{RESEARCH METHODOLOGY}

This type of research is qualitative research. This research has the meaning that it is a research procedure that produces descriptive data in the form of words or writings and the behavior of people who are observed in a certain context which is studied from a complete, comprehensive, and holistic point of view. ${ }^{11}$ Data collection techniques were the interview and data collection through literature studies. An interview is a meeting of two people to exchange information and ideas through question and answer, so that meaning can be constructed in a particular topic. ${ }^{12}$ Data were collected from documents such as scientific journals, books, and dictionaries by analyzing texts or discourses that investigate an event or writing being studied to get the right facts. ${ }^{13}$

\section{THE CONCEPT OF POLITICAL NATIONALISM}

Politics has several meanings: knowledge of membership or statehood; all matters and actions (policies, tactics, etc), regarding the government of the country or against other countries; how to act in the face or deal with a problem. ${ }^{14}$ According to Michael G Roskin, politics is a competition that takes place between people, usually in groups, to make policies according to their wishes. ${ }^{15}$ Competition between humans for power, whether in classical political systems such as the kingdom, khilafah, or the sultanate as well as modern systems such as the current democratic system. So, the two terms are only at the level of language, while at the level of objectives there are

${ }^{10}$ Zulfadli, "Kontestasi Ormas Islamis Di Indonesia," Al-Tahrir: Jurnal Pemikiran Islam 18, No. 1 (Mei 2018): 69.

${ }^{11}$ Amir Hamzah, Metode Penelitian Kualitatif (Malang: Literasi Nusantara, 2019), 35.

${ }^{12}$ Sugiyono, Metode Penelitian Kombinasi (Bandung: Alfabeta, 2016), 316.

${ }^{13}$ Hamzah, Metode Penelitian Kualitatif.

${ }^{14}$ Departemen Pendidikan Nasional, Kamus Besar Bahasa Indonesia (Jakarta: Balai Pustaka, 2005), 886.

${ }^{15}$ Michael G Roskin, Pengantar Ilmu Politik (Jakarta: Kencana, 2016), 3. 
similarities, namely the scope of the state, to realize the goals of the State. ${ }^{16}$

Meanwhile, the meaning of nationalism comes from the word nation which has two meanings, namely anthropological and sociological terms. A nation is a society that is an independent living community and each member of the community feels a unity of race, language, religion, history, and customs. ${ }^{17}$ Rupert Emerson, as quoted by Adhyaksa Dault, defines nationalism as a community of people who are united on the basis of deep important elements of a common heritage and have a common destiny towards the future. ${ }^{18}$ Ernest Renan as quoted by Ali Masykur Musa said that the existence or non-existence of a nation depends on the will of the individual: the inhabitants of a region that emerged historically, who see themselves with nationality. So the nation is a great unity of solidarity, created by a feeling of sacrifice that has been made in the past and which the human beings concerned is willing to make in the future. ${ }^{19}$

Based on this explanation, nationalism politics is a common solidarity unit that is manifested in a single political order that gives birth to the form of a Nation-State. This is based on the historical fact that the imperial model as it has happened in the past is no longer possible to be realized. Apart from the human nature which is provincialism and particularism, unifying Muslims does not have to be in one power, but different powers with the same spirit of Islamic morality. ${ }^{20}$

\section{THE POLITICS OF NATIONALISM IN THE KIRAB SATU NEGERI \\ GP ANSOR}

Kirab is a joint trip or parade. ${ }^{21}$ GP Ansor conducted a trip throughout Indonesia from Sabang-Merauke. They have a political goal of

${ }^{16}$ Inu Kencana Syafii and Azhari, Sistem Politik Indonesia (Bandung: Refika Aditama, 2012), 6.

${ }^{17}$ Adhyaksa Dault, Islam Dan Nasionalisme, Reposisi Wacana Universal Dalam Kontek Nasional (Jakarta: Pustaka Al-Kautsar, 2005), 1-2.

${ }^{18}$ Dault.

19 Ali Masykur Musa, Nasionalisme Di Persimpangan (Jakarta: Penerbit Erlangga, 2011), 61.

${ }^{20}$ Tamara Sonn, Islam A Brief History (UK: Wiley-Blackwell, 2010), 134.

${ }^{21}$ Nasional, Kamus Besar Bahasa Indonesia. 
nationalism, namely one language, one nation, and one Indonesian homeland. Because in the Indonesian context the formation of nationalism politics was based on the following facts: First, the genetic diversity factor (heredity) of ethnic groups, and families. Second, geographic, namely climate, soil conditions, local natural resources, fauna, and flora. Third is historical, namely events, important events, natural disasters, upheaval, common fate. Fourth is psychological, namely attitude, a unique way of acting and acting so that it becomes a habit, a distinctive character. These factors bind all the various ethnic groups, ethnicities, and religions to declare themselves as a unity in the nation. A nation is a society that is an independent living community and each member of the community feels a unity of race, language, religion, history, and customs. ${ }^{22}$ Promoting nationalism politics is a must for GP Ansor. This is because it concerns the existence of the state and the nation. When this is not maintained, it could set a bad precedent for the unitary state of Indonesia as a result of the actions of radical groups who want a caliphate. Of course, it refers to the nature of politics itself which is related to issues of government, power, conflict, political parties, or the efforts taken by individuals or groups to fight for the interests of a citizen in general. There are at least five views of understanding politics. First, politics are the efforts taken by citizens to discuss and realize the common good. Second, all matters relating to the administration of the state and government. Third, politics is all activities to seek and maintain power in society. Fourth, politics are activities related to the formulation and implementation of general policies. Fifth, politics is looking for and/or maintaining important sources. ${ }^{23}$

The choice of political nationalism is to the historical fact that the state was born based on political compromise from diverse ethnic, ethnic, religious, and cultural backgrounds. Because only political nationalism can build a mechanism for the running of politics in society to run with the principle of intense communication between

${ }^{22}$ Dault, Islam Dan Nasionalisme, Reposisi Wacana Universal Dalam Kontek Nasional."

${ }^{23}$ Mirhan AM, "Agama Dan Politik Di Kalimantan Selatan," Ilmu Ushuluddin 15, No. 2 (July 2016): 115. 
the community and their leaders with the form of an organization and leadership, be it political, economic, or religious. ${ }^{24}$

According to Abdul Latief Syakur, every citizen has the right and obligation to participate in efforts to defend the state and the conditions for state defense have been regulated in law. The awareness of defending the country is essentially dedicated to the state and willing to sacrifice to defend the country. Furthermore, according to him, if someone dies on the way or dies in a war to uphold God's religion, to defend his line and homeland, to refuse an enemy who threatens the sovereignty of the country, he will receive two rewards, namely the reward from Allah and the reward in the world. ${ }^{25}$

\section{THE IMPLEMENTATION OF THE NATIONALISM POLITICS OF KIRAB SATU NEGERI HELD BY KSN GP ANSOR IN THE MERANTI ISLANDS DISTRICT}

\section{Rejecting the Khilafah state system modeled by HTI and FPI}

The rationale for the birth of the national KSN movement is one of the main agendas, namely rejecting radicalism groups that threaten the Unitary State of the Republik of Indonesia. At each Basic Education and Training (Diklatsar) GP Ansor participants are always provided with material on religion and nationalism. This material is a provision for them to understand the mission of the organization as a noble mission, namely to defend the Republic of Indonesia. GP Ansor is ready to defend this NKRI which is considered by HTI as al-nidam al-jahily (the order of the jahiliyyah society) and falsehood (deviant) and is taghut. ${ }^{26}$

According to Purwaji, the head of PW Ansor Riau, this KSN activity is part of promoting nationalism to the general public. According to him: ${ }^{27}$

${ }^{24}$ Amin Heri Susanto, "Hukum Mendirikan Partai Politik Perspektif Islam: Refleksi Islam Politik Klasik Dan Modern," Yudisia Jurnal Pemikiran Hukum Dan Hukum Islam 11, No. 1 (June 2020): 157.

${ }^{25}$ Ridhoul Wahidi, "Konsep Nasionalisme Perspektif Syaikh Abdul Latief Syakur," Religia Jurnal Ilmu Ilmu Keislaman 22, No. 2 (2019): 273.

${ }^{26}$ Nugraha, Fundametalisme Pendidikan Agama Di Jejaring Sosial.

${ }^{27}$ Purwaji, "interview on Kirab Satu Negeri in Kabupaten Kepulauan Meranti," Pebruari 2020. 
The KSN activity has a mission, which is to raise a spirit of nationalism in the wider community so that they love the Republic of Indonesia more and not to be exposed to the poison of radicalism fighting for the caliphate which is increasingly massive and open in various media including Social Media.

Purwaji's words clearly show the purpose of KSN activities as a form of nationalism which HTI considers tobe false (deviant) and taghut. ${ }^{28}$ The HTI movement as an underground political party continues to infiltrate through struggles of thought and distorting society through Mass Media to attract sympathy. And this effort began to be successful with the judgment of some of the community on the burning of the Tauhid flaq which they claimed was not the flag of HTI. Such patterns are continuously being carried out which are very dangerous to Pancasila ideology as the unifier of the nation and state.

\section{Embracing and protecting the meranti community}

The basic character of GP Ansor's nationalism politics is to embrace and protect all levels of society in the diversity of ethnicities, religions, and cultures. This was also done during the KSN acitivities, GP Ansor invited all people to build brotherhood through drinking coffee water together with the headline "A Thousand Coffes" in various Shops located on the edge of the Selatpanjang Sea. Anyone can drink for free across ethnicities and religions. This event is an effort to build togetherness and open space for dialogue with the entire community. ${ }^{29}$

The politics of nationalism in the form of embracing and protecting the people of Meranti have been carried out by GP Ansor of the Meranti Islands. Khosairi said:

In various events such as the commemoration of national holidays, GP Ansor always participates in the offices of regents, subdistricts, and villages. Likewise, when people hold cooperation, we are always present. Including non-Muslim like our brothers

\footnotetext{
${ }^{28}$ Nugraha, Fundametalisme Pendidikan Agama Di Jejaring Sosial.”

${ }^{29}$ Purwaji, "interview on Kirab Satu Negeri in Kabupaten Kepulauan Meranti."
} 
from the Chinese who also participated in securing the event at its peak. $^{30}$

This fact shows that the attitude of openness of GP Ansor to all elements of society is a form of identity politics which is often played by radicalism groups. All people have the same rights to jointly develop the state and nation as long as they have the ability in their respective fields. It is because the obligation to defend the country is not only by Muslims but all walks of life. Defending ranks and homeland, rejecting enemies who threaten the sovereignty of the country get two rewards, namely from Allah and rewards in the World. $^{31}$

\section{The freedom of the family and members of the GP Ansor in practical politics}

The National KSN GP Ansor activity is an activity to make the public and youth aware of the importance of nationalism in the nation and state. According to the chairman of The GP Ansor Center Yaqut Cholil Qoumas, the goal of KSN is purely an activity to revive a sense of nationality, the feeling of one Indonesia. This is a form of concern over the existence of groups that intend to change or destroy the consensus of the Indonesian nationality and use religion as a political tool and a source of conflict. ${ }^{32}$ So this is a form of the responsibility of NU youth to strengthen the consensus of the Indonesian nation in determining the basis of the state, namely Pancasila, and to strengthen the function of religion as a blessing and a source of peace.

Purwaji in an interview with the author said:

$G P$ Ansor does not limit and prohibit its members from joining any political party. For example, members of the GPAnsor Meranti are members of multi political parties, there are PPP, PKB, PAN, PDIP, and Gerindra and there are even PKS activists. GP Ansor also did not question political rights to elect the preferred presidential candidate. Please want to vote for Jokowi-Ma'ruf, please, choosing Prabowo-Sandi is no problem. So, don't think of

${ }^{30}$ Khosairi, “ interview on Kirab Satu Negeri in Kabupaten Kepulauan Meranti," February 2020.

${ }^{31}$ Wahidi, "Konsep Nasionalisme Perspektif Syaikh Abdul Latief Syakur."

${ }^{32}$ Yaqut Cholil Qoumas, Kirab Satu Negeri, GP Ansor Bertolak Dari Gejala Pilkada DKI, CNN, September 16, 2018. 
this KSN activity as a mouthpiece for a particular presidential and cawapres candidate. That's a big mistake. This activity is purely a form of national politics. ${ }^{33}$

Based on these facts, GP Ansor has detected unhealthy politics carried out by the radicalism group by using political issues to reject the agenda of KSN activities in the Meranti Islands. They clashed against the two supporters of the 2019 presidential and vicepresidential candidates so that a clash occurred in the community. That is the target wanted by the radicalism group. In this case, they succeeded. So that there was an incident of persecution against the GP Ansor.

Radical groups cannot attack the government openly at a time when they do not have maximum power. However, what is clear is that transformative movements (movements that are changing), do not take into account the diversity of ethnicities and religions. Symptoms such as easy to accuse of disbelief between Muslims who are of different politics and closing the door to non-muslim in politics and the aspirations of upholding Islamic law in state life show an attitude of exclusivity in politics. ${ }^{34}$

They took advantage of the momentum of the Presidential Election to carry out tafa'ul (interaction) with the community to develop Islamic $d a$ 'wah by forming an awareness and general opinion on the ideas and Islamic law that had been selected and established. They carry out collective stages, including safaqah al-murakkazah, through halaqah in building a movement framework, saqafah aljama'iyah, through intellectual activity and scientific publications, sira al-fikry, through struggles of thought to oppose various other ideologies, and kaifah al-siyasi, through political struggle based on syara' law, and the final stage, namely conducting a coup to take power. The last pattern was carried out when sira al-fikry was able to dominate the thinking of the Islamic community and was able to create an atmosphere of distrust towards the legitimate government. ${ }^{35}$

${ }^{33}$ Purwaji, “ interview on Kirab Satu Negeri in Kabupaten Kepulauan Meranti."

${ }^{34}$ Fuad, "Gerakan Kultural Dan Pemberdayaan: Sebuah Imun Terhadap Radikalisasi Di Sanggar Sekar Jagad Sukoharjo."

${ }^{35}$ M. Imdadun Rahmat, Arus Baru Islam Radikal Revivalisme Islam Timur Tengah Ke Indonesia (Jakarta: Penerbit Erlangga, 2005). 


\section{IMPLICATION OF KSN ON THE NATIONALISM POLITICS OF GP ANSOR IN MERANTI ISLANDS REGENCY}

The implementation of KSN activities is a very important event in realizing political diversity in various religious activities such as grave pilgrimages to the graves of warrios and scholars, istighosah, and grand recitations and pledges of loyalty to the Republic of Indonesia. The GP Ansor has succeeded in embracing all components with diverse political views, especially the issue of the 2019 presidential election. However, these goals did not materialize. The KSN activity turned out to have very painful implications for the GP Ansor of the Meranti Islands. Here are some of the implications:

First, rejection of LAM, HTI, FPI, and Youth Organizations. The rejection of KSN activities was felt when the riots broke out in Pekanbaru city, then spread to various districts of Siak, Bengkalis, and Meranti Islands. The persecution of this activity in the Meranti Islands Regency involved the Malay Customary Institution (LAM), HTI, FPI, and youth organizations as Pemuda Pancasila and Pemuda Panca Marga. Khosairi stated:

All existing mass organizations refuse KSN activities. The port for two days was blockaded by youth organizations. Some of them gave speeches at Taman CikPuan while saying inappropriate words to GP Ansor. They are ready to refuse the arrival of PW Ansor Riau and Islamic scholars from Cirebon who be a resource person. ${ }^{36}$

Their rejection of these activities was based on the excuse that it created a conducive district condition and maintained harmony. Because according to them, the KSN event could confuse the situation. Of course, this is contrary to the facts because the presence of GP Ansor in Meranti has been a long time since 1965 and helps the community in every socio-religious activity. ${ }^{37}$ This includes helping to secure the activities of other religious communities such as the Chinese New Year event Tionghoa. ${ }^{38}$

\footnotetext{
${ }^{36}$ Khosairi, "interview on Kirab Satu Negeri in Kabupaten Kepulauan Meranti."

${ }^{37}$ Kholik, "interview on Kirab Satu Negeri in Kabupaten Kepulauan Meranti."

${ }^{38}$ Khosairi, "interview on Kirab Satu Negeri in Kabupaten Kepulauan Meranti."
} 
Second, Damaging the image of Islam and Malay culture. LAM, HTI, FPI, and youth organizations rejected the KSN GP Ansor activities because they were deemed to have damaged the image of Islam. Some activities such as guarding the Church and other places of worship are acts that are too dear to the minority rather than the majority. Also, the attitude of GP Ansor in various regions has rejected Ustadz Abdul Somad (UAS) recitation in various regions in Central Java. This action was considered as contradicting the status of GP Ansor, who always defended the scholars.

In response to this, Khosairi said the following:

Banser guard the Church in other places, and protects our brothers from the Chinese community who celebrate the Chinese New Year does not contradict the teaching of Islam. This is part of humanitarian jihad so that the implementation of their activities is not disturbed by irresponsible people. GP Ansor must be present to protect minorities. Don't let them feel uncomfortable due to interference from the majority group. About why not guarding the mosque, because we have all guarded it, namely by praying at the Mosque. $^{39}$

As for the accusation that GP Ansor Persecuted UAS, Khosairi explained that this was not true. Incidents that accured in various regions in Central Java and the cancellation of UAS at various recitation events did not carry out persecution, but GP Ansor did not want HTI elements to carry out the recitation program, who often took advantage of the UAS recitations. In addition to the various Tabligh Akbar or Islamic Lecture held by UAS in various regions in Riau, GP Ansor always escorted him, including in the Meranti Islands Regency. ${ }^{40}$

Third, become a presidential candidate campaign team for Jokowi-Ma'ruf. Mass organizations such as HTI, FPI, Pemuda Pancasila, Pemuda Panca Marga, and all youth organizations rejected this event. Even the Chairman of the Malay Custmoray Institution (LAM) Datuk Seri H. Ridwan Hasan, who previously accepted it the following day, firmly rejected it the following day, firmly rejected the implementation of KSN activities encapsulated

\footnotetext{
${ }^{39}$ Khosairi.

${ }^{40}$ Khosairi.
} 
in national remembrance. They have accused GP Ansor of spreading Islam Nusantara teaching as heratical teachings and discussing UAS recitation in various areas of Central Java.

Purwaji, Head of PW Ansor Riau Province, has mediated and called UAS and was never picked up. He publicly made a video apology that was shared on Social Media. Purwaji on various occasions gave explanations related to events in Central Java as a form of anticipation for HTI inflitration in UAS recitation. He also explained the UAS recitation escort activities by GP Ansor members in various districts, including carrying out escorts in the Meranti Islands Regency. However, all these facts were not accepted by the mass organizations and LAM of the Meranti Islands Regency. ${ }^{41}$

Khosairi also explained the fact that the members of the $G P$ Ansor consist of various political parties. He said that it was not true that this KSN activity had become a practical political agenda to win the pair of JokoWidodo and Ma'ruf Amin. We from the committee invited all existing elements, both the local government, all mass organizations, and the community. Besides many of our members are from political parties that support Prabowo-Sandi, such as the Gerindra, PAN, and PKS parties. So the accusation was too much so that even the recitation activity was considered a political activity. ${ }^{42}$

Fourth, the split of GP Ansor in response to KSN activities. The black campaign was very intense by radicalism groups and groups that hate GP Ansor through various places such as place of worship through recitation and Friday sermons and massive Social Media. So that almost every time the insults and insults against the $G P$ Ansorwere the most common themes. This turned out to affect the psychology of some members of the GP Ansor who were provoked and had a different attitude to the nationalist politics outlined by the Central GP Ansor.

Khosairi said:

I am especially disappointed with my friends who have served as administrators of the GPAnsor, and have even been the chairman of the GPAnsor by blatantly insulting the organization by accusing them of being inappropriate. As a reslut, this spread to some other Ansor members who were unaware of the problems occurring in

\footnotetext{
${ }^{41}$ Purwaji, “ interview on Kirab Satu Negeri in Kabupaten Kepulauan Meranti."

${ }^{42}$ Khosairi, " interview on Kirab Satu Negeri in Kabupaten Kepulauan Meranti."
} 
various regions. But I have to save this organization. The current political situation is very tough. Whatever happens, the KSN event must continue. ${ }^{43}$

Khosairi's words showed that the effect of persecution on the solidity of the members of the GP Ansor. This is because there are different political views in the preidentialelektion as well as negative opinions formed in the community that GP Ansor is an organization that insults scholars and tarnishes Islam by calling Islam in Indonesia the Islam of the Archipelago and has dared to burn the Tauhid Flag.

According to Panuji, as quoted by Irtanto, public opinion is considered valuable because: first, public opinion represents an image of superiority, so there is a belief that whoever controls public opinion will be able to control others. Second, public opinion represents factual reality, so that individuals feel they must respond as a way of showing their existence. Third, public opinion is related to image, plan, and operation. Fourth, public opinion reflects what many people want. Fifth, public opinion is identical to ideological hegemony. ${ }^{44}$

This provocation was successful. The Islamic Community, both from modernist muslims such as Muhamadiyah or some politicians and NU figures, also criticized the activities of KSN GP Ansor. They commit cybercrime by using social media such as facebook and twitter. They also carry out political inflintrasi through lectures at Mosques and Islamic holidays. The material revolves around the government is not pro-Islam, the burning of the HTI Flag which is perceived as the Tauhid Flag in Garut by GP Ansor members, and the blaspheming of religion.

\section{SETTLEMENT OF THE NATIONALISM POLITICAL PERSECUTION OF THE GP ANSOR IN THE MERANTI ISLAND}

The implication of persecution of youth organizations and LAM does not make GP Ansor provoke a heated situation. The main board of the GP Ansor, who has high militancy, has made various efforts to resolve the issue, including:

${ }^{43}$ Khosairi.

${ }^{44}$ Irtanto, Dinamika Politik Lokal Era Otonomi Daerah (Yogyakarta: Pustaka Pelajar, 2014), 158-59. 
First, creating transparent information about KSN activities. Chairman Khosairi accompanied by Slamet as secretary of the $G P$ Ansor held an open dialogue facilitated by the regional government of the Meranti Islands District. In the meeting room, all representatives of youth organizations, MUI, deputy regent, and LAM. Khosairi explained that the KSN program was purely building a national spirit through the oath of loyalty to the Republic of Indonesia and Tabligh Akbar. Even if they are still in doubt, he also invites all mass organizations, MUI, and the Local Government to attend Tabligh Akbar at the event. In this meeting, Chairman of LAM H. Ridwan Hasan, deputy regent or Drs. Said Hasyim, and the chief of police agreed to the implementation of the Akbar recitations as the core of KSN activities. ${ }^{45}$ The openness attitude carried out by GPAnsor proves that this activity is purely a recitation activity and a pledge of loyalty to the NKRI as the core activity of the KSN in the Meranti archipelago regency.

The openness attitude carried out by GP Ansor proves that this activity is purely a recitation activity and a pledge of loyalty to the NKRI as the core activity of the KSN in the Meranti Archipelago Regency. The values of nationalism here are offered by GP Ansor, namely prioritizing dialogue and information disclosure for all KSN activities. This is part of the family values that characterize GP Ansor in solving problems.

Second, the cultural approach of the customary Malay Community carried out by NU. However, the Malays of the Meranti Islands Regency are less familiar with the term NU culture, they are more familiar with the term "Kaum Tua Group". Khosairi said:

The Malay community does not say part of NU, but culturally they have practiced NU teachings such as the tradition of reading al-Barjanzi, visiting the grave, reading tahlil, wiridan after the five daily prayers, taraweh prayers 20 rakaat, and Jum'ah prayers using two adzan. I also came to visit H. Ridwan Hasan as a Malay figure who stated that the KSN event contained istighasah, tahlil, prayer together and the lecture Islamic which had become a tradition in Malay society. This excuse is accepted. Even the Chairman of

${ }^{45}$ Khosairi, “ interview on Kirab Satu Negeri in Kabupaten Kepulauan Meranti.” 
LAM Ridwan Hasan, and approved the implementation of the activity. $^{46}$

Third, build a structural approach. Khosairi also took an individual approach to important officials in the regional government of the Kepulauan Meranti Regency, such a Irwan Nasir (Regent), Fauzi Hasan (Chairman of The Members of The Regional Parliament or DPRD), and AKBP Laode Project (The Chief of District Resort Police or Kapolres). After the individual meeting, a joint meeting was continued at the Regent's Office. The result of the decision was that the event of the Lecture Islamic recitation was still carried out following the agenda set by the Grand Committee of GP Ansor Jakarta and received full support from the head of the Meranti Islands Regency Police. ${ }^{47}$

Fourth, build a spiritual approach. After finishing the peak event of the Lecture Islam, at night around 02.00 in the morning, around 100 Ansor members performed mujahadah asking Allah Swt. for help. The goal is that all disasters do not happen to the GP Ansor family, families, and communities. Even during the prayer session, the groups that carried out the persecution became brothers and sisters of fellow Muslims and lost their resentment. ${ }^{48}$

Activities with a spiritual approach prove that GP Ansor has a strong tradition of religious practice as a form of religious nationalism. So gpansor's religious practice as a form of religious nationalism. So GP Ansor's accusation of being an unreligious mass organization is automatically refuted. Moreover, GP Ansor has traditons such as mujahada such as midnight prayers, Sunnah fasting, and memorizing al-Qur'an, and the tradition of reading the books of previous Scholars at certain moments. However, due to the political problems of radicalism groups, the reality of the GP Ansor in framing is so bad that people are provoked and follow their political plans.

\section{CONCLUSION}

Based on the research above, in the Meranti Archipelago, GP Ansor in the activities of KSN can be concluded as follow: first, the implementation of nationalism politics as a whole agrees to reject

\footnotetext{
${ }^{46}$ Khosairi.

${ }^{47}$ Khosairi.

${ }^{48}$ Purwaji, "interview on Kirab Satu Negeri in Kabupaten Kepulauan Meranti."
} 
radicalism which wants the establishment of an Islamic caliphate which infiltrated and openly supported the presidential and vice Prabowo-Sandi presidential candidates. They deliberately infiltrated the goal of dividing the brotherhood that the GP Ansor and the surrounding community since 1965 . Besides, the manifestation of the implementation of nationalism politics in KSN is to invite all levels of society of different ethnicities, religions, and cultures to jointly have a relaxed dialogue in the headline "a thousand coffees" at Coffe Shops on the Seafront. On the other hand, the KSN event is purely a national politics, the GP Ansor management also allows its members to become administrators or candidates for the board of various political parties and support one of the presidential candidates.

The strong persecution and the arousing of negative carried out HTI, FPI, and Youth Organizations through various media such as in places of worship, places of lectures Islamic, and social media greatly affect the psychology of some members of the GP Ansor. Therefore, some of them are also evaluated negatively and blamed for some of the activities carried out by GP Ansor. The members militant administrators patiently and consistently try to solve the persecution problem that befell them with the spirit of nationalistic values in the form of such as opening up spaces for dialogue with mass organizations that refuse KSN events, building a structural relationship with the local government, members of the regional parliament, LAM, and also society building cooperation for the common safety of the nation and state from radicalism groups.

\section{REFERENCES}

Adzim, Abdul. "Religious Harmonization as Deradicalisation Efforts Through Interfaith Communities - A Case Study of the Religious Communication Forum (FKUB) in Pekalongan City." Islamic Studies Journal for Social Transformation 3, No. 1 (2019): 21.

AM, Mirhan. "Agama Dan Politik Di Kalimantan Selatan.” Ilmu Ushuluddin 15, No. 2 (July 2016): 115. 
Dault, Adhyaksa. Islam Dan Nasionalisme, Reposisi Wacana Universal Dalam Kontek Nasional, 1-2. Jakarta: Pustaka AlKautsar, 2005.

Fuad, A. Jauhar. "Gerakan Kultural Dan Pemberdayaan: Sebuah Imun Terhadap Radikalisasi Di Sanggar Sekar Jagad Sukoharjo." At-Tahrir Jurnal Pemikiran Islam 18, No.1 (Mei 2018): 3 .

Gumiandari, Septi, and Nafi'a Ilman. "The Role of Cirebon Women Ulama in Countering Religious Radicalism." QIJIS (Qudus International Journal of Islamic Studies) 8, No. 1 (2020): 1.

Hamzah, Amir. Metode Penelitian Kualitatif, Malang: Literasi Nusantara, 2019.

Irtanto. Dinamika Politik Lokal Era Otonomi Daerah, Yogyakarta: Pustaka Pelajar, 2014.

Kholik, Kyai. "Interview on Kirab Satu Negeri in Kabupaten Kepulauan Meranti," 2020.

Khosairi. "Interview on Kirab Satu Negeri in Kabupaten Kepulauan Meranti," Pebruari 2020.

Musa, Ali Masykur. Nasionalisme Di Persimpangan, Jakarta: Penerbit Erlangga, 2011.

Nasional, Departemen Pendidikan. Kamus Besar Bahasa Indonesia, Jakarta: Balai Pustaka, 2005.

Nugraha, Muhamad Tisna. "Fundametalisme Pendidikan Agama Di Jejaring Sosial." Al-Tahrir: Jurnal Pemikiran Islam 18, No.1 (Mei 2018): 51.

Purwaji. "Interview on Kirab Satu Negeri in Kabupaten Kepulauan Meranti," Pebruari 2020.

Qoumas, Yaqut Cholil. "Kirab Satu Negeri, GP Ansor Bertolak Dari Gejala Pilkada DKI." CNN, September 16, 2018.

Rahmat, M. Imdadun. Arus Baru Islam Radikal Revivalisme Islam Timur Tengah Ke Indonesia. Jakarta: Penerbit Erlangga, 2005. Roskin, Michael G. Pengantar Ilmu Politik, Jakarta: Kencana, 2016. 
Sihombing, Husnul Habib, and Erianjoni Erianjoni. "Internalisasi Nilai-Nilai Aswaja Pada Organisasi Gerakan Pemuda Ansor Di Kota Padang.” Jurnal Perspektif 1, No. 4 (2018).

Solichun, Imam. "Peran Organisasi Pemuda Dalam Menangkal Radikalisme (Studi Pada GP Ansor Kota Surabaya Periode 2017-2021)." PascaSarjana Universitas Islam Negeri Sunan Ampel Surabaya Tesis (2018).

Sonn, Tamara. "Islam A Brief History," 134. UK: Wiley-Blackwell, 2010.

Subakir, Ahmad, and Ahmad Khoirul Mustamir. "Gerakan Moderasi Islam Dalam Perspektif Deteksi Dini; Studi Gerakan Pemuda Ansor Kota Kediri." Tribakti: Jurnal Pemikiran Keislaman 31, No. 2 (July 2020).

Sugiyono. Metode Penelitian Kombinasi, Bandung: Alfabeta, 2016.

Susanto, Amin Heri. "Hukum Mendirikan Partai Politik Perspektif Islam: Refleksi Islam Politik Klasik Dan Modern." Yudisia Jurnal Pemikiran Hukum Dan Hukum Islam 11, No. 1 (June 2020): 157.

Syafii, Inu Kencana, and Azhari. Sistem Politik Indonesia, Bandung: Refika Aditama, 2012.

Wahidi, Ridhoul. "Konsep Nasionalisme Perspektif Syaikh Abdul Latief Syakur." Religia Jurnal Ilmu Ilmu Keislaman 22, No. 2 (2019): 273.

Zulfadli. "Kontestasi Ormas Islamis Di Indonesia." Al-Tahrir: Jurnal Pemikiran Islam 18, No. 1 (Mei 2018): 69. 